\title{
A hut too far: history of the Argentine Ventimiglia shelter on Peter I Øy
}

\author{
Pablo Gabriel Fontana \\ Instituto Antártico Argentino, Buenos Aires, Argentina
}

\begin{abstract}
This paper addresses the barely known history of an Argentine Antarctic hut: the Teniente Luis Ventimiglia hut, installed by the Argentine Antarctic Institute on Peter I Øy (Peter I Island) in March 1971. In examining the history of the only Argentine Antarctic facility outside of the Argentine Antarctic Sector, this article describes the reasons behind the establishment of the hut and the scientific work that took place there as well as previous Argentine expeditions to Peter I.
\end{abstract}

\section{KEYWORDS}

Instituto Antártico

Argentino; Argentine Antarctic Institute;

Antarctica; General San

Martin icebreaker; Peter

I Island

\section{ABBREVIATIONS}

DNA: National Antarctic

Directorate (Dirección

Nacional del Antártico); IAA:

Argentine Antarctic Institute

(Instituto Antártico

Argentino); LCVP: landing

craft, vehicle, personnel boat

(also known as a Higgins

boat); SMN: National

Meteorological Service

(Servicio Meteorológico

Nacional)
On 3 March 1971 a group of scientists from the IAA inaugurated the Teniente (Lieutenant) Luis Ventimiglia hut on Peter I Øy (Peter I Island). This became the most remote Argentine shelter in Antarctica, and it is the only IAA construction outside the Argentine Antarctic Sector (between $25^{\circ} \mathrm{W}$ and $74^{\circ} \mathrm{W}$ ). The history leading to this episode began in 1953, when the Argentine Navy decided to send the transport vessel ARA Bahía Buen Suceso, under the command of frigate captain Héctor Iglesias, to that island. During the 1953/54 summer Antarctic Campaign the vessel reached just $60 \mathrm{~km}$ short of Peter I $\varnothing y$ and could not get closer because of the pack ice. This was not the first time this happened: the Russian explorer Bellingshausen, who discovered the island in 1821 and named it in honour of the Russian Emperor, did not approach closer to the island than $25 \mathrm{~km}$. The French explorer Charcot was luckier: he came as close as $5 \mathrm{~km}$ from the island, confirming its existence. The Norwegian expedition of 1926/27, led by Eyvind Tofte, could not disembark either, but his fellow countryman Nils Larsen did, on 2 February 1929, when he claimed the island for Norway. Another successful landing on the island was the Norwegian expedition with the ship Brategg, which was also captained by Larsen; the expedition carried out biological, geological and hydrographical investigations for three days (Barr 1987).

After the first Argentine attempt, Peter I Øy remained off the Argentine agenda for a decade. In early 1964, however, the General Staff of the Argentine Navy instructed that studies be undertaken to determine the feasibility of establishing and maintaining a meteorological station at the site during most of that year's Antarctic campaign, to improve weather forecasting for the Antarctic Peninsula (Coli 2003). Peter I Øy is to the east of the Antarctic Peninsula, whereas the majority of Argentine stations are located on the western coast of the peninsula and islands located to its west: Carlini (at the time known as Jubany), San Martín, Melchior, Cámara, Brown and Decepción. On 29 April 1964, the Antarctic Naval Group conducted a study to investigate the possibilities for establishing a weather station on Peter I, but found that the situation was not very promising: the weather is hostile, the ice sea is extremely variable and the mountainous geography and glaciers make reaching the island and working on it hazardous (Estado Mayor del Grupo Naval Antártico 1964). During the 1959/60 austral summer, the Soviet Union's attempt to establish a meteorological station on this island had proved unsuccessful. 


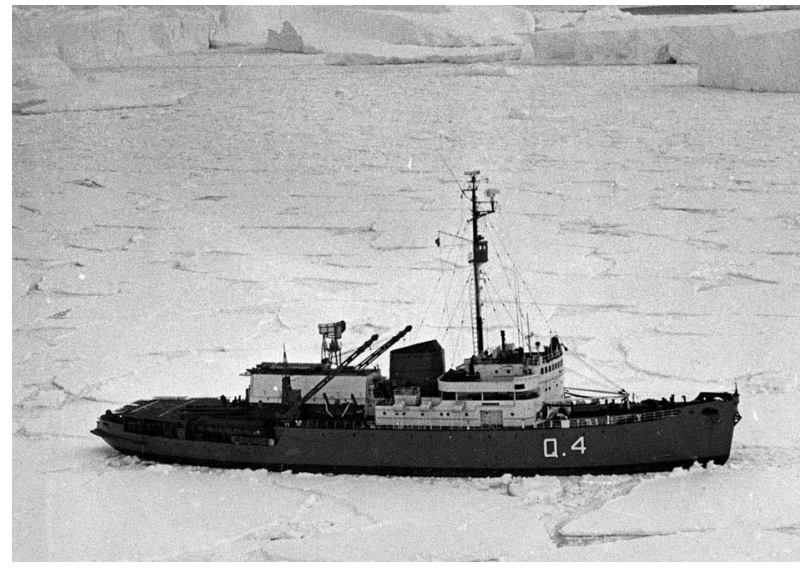

Figure 1. The icebreaker ARA General San Martín sailing in Antarctica. (DNA-IAA Archive of Historical Photography, AFH000910.)

Notwithstanding the difficulties, the Argentine Navy Antarctic Force proposed a logistic plan that included the use of the icebreaker ARA General San Martín (Fig. 1), as well as helicopters, to transport equipment from the vessel to the island (Estado Mayor del Grupo Naval Antártico 1964). The operation depended on the glacio-meteorological conditions and there was no assurance of external assistance in an emergency, as the icebreaker could be held up with other activities in the peninsula or Weddell Sea regions. The study concluded that the operation was not feasible and General Staff received the recommendation not to establish the station (Estado Mayor del Grupo Naval Antártico 1964).

Nonetheless, that same year a complete survey of the island was undertaken and in early February 1965, the icebreaker ARA General San Martín, after calling at San Martín Station on the western side of the Antarctic Peninsula, headed towards Peter I Øy. The vessel under the command of frigate captain Gonzalo Demetrio Bustamante, instructions were to conduct a general reconnaissance of the area and to determine the limits of the sea ice, anchoring areas, disembarkation points as well as potential helicopter and DHC-2 Beaver airplane landing sites (Coli 2003).

On 11 February the icebreaker crew came within sight of the island and carried out oceanographic studies. The following day the vessel anchored in Sandefjordbukta and lowered an LCVP landing craft to attempt disembarking. This proved unsuccessful because of the very steep coastline (Armada de la República Argentina 1965). The vessel would go on to circumnavigate the island at an average distance of $3.5 \mathrm{~km}$ for six hours and returned to anchor in the same position. The weather conditions over the island changed rapidly, making any activity increasingly difficult. After finalizing the reconnaissance, the vessel headed back towards the Antarctic Peninsula without any promising results.
The rough conditions did not, however, discourage the Argentines, who, six years later, completed their proposed plan. By mid-February 1971 the icebreaker ARA General San Martín, now under the command of frigate captain Dalton Alurralde, left Ushuaia for the fourth stage of its annual voyages, with nine people on board specifically for the mission to Peter I Øy. Among them was the logistics expert from the DNA, Héctor Pascual Agüero Urquiza, as well as Raúl Leguina, Cristóbal Haben Pino, the brothers Reynaldo and Gerónimo Soto of the SMN, the technicians of the IAA, Mario Rosario Cassis and Félix Andrónico Castro, and the biologist of this same institute, Aldo Pascual Tomo (Antarctic Naval Force 1971). Some of the members of the group had overwintered in Antarctica many times and Ortíz had also participated in the Argentine terrestrial expedition to the South Pole in 1965 (Leal 1971).

On 24 February, after sailing from San Martín Base, on Barry Island, the ARA General San Martín once again headed towards Peter I, which it reached a week later. On 2 March at 16:00, a first flight was performed with a Navy Aviation Alouette III S-31 helicopter with the director on the IAA, Guillermo Mackinlay, and the Antarctic commander, Captain Roberto Ulloa, on board. During that dangerous flight, under whiteout conditions, landing at Evaodden (Eva cape) was made possible by the use of coloured smoke grenades to visualize the ground. Once on land, Mackinlay expressed his profound happiness, claiming to have been waiting 18 years for that moment since the first conceived plan onboard the ARA Bahía Buen Suceso in 1953 (Ulloa, pers. comm.).

The same day, three hours after of the first flight, an Argentine Air Force UH-1H Huey helicopter transported scientists and logistics personnel, camp equipment and the prefabricated shelter. The group undertook several scientific studies and established a camp in the vicinity of Evaodden (Cabo Odd on the 1973 map), some $500 \mathrm{~m}$ from the coast, southeast of Tvistein Pillars (Fig. 2). The men began to assemble the shelter and, the following day, the seven members from the DNA-IAA and the two from the SMN were taken to the site, where they carried out a series of scientific measurements. Among the activities was the exact determination of the coordinates of the island, possibly motivated by a report by the IAA glaciologist César A. Lisignoli dated 31 August 1970, in which he stated that its geographical position was not well determined on account of different positions given by previous expeditions (Lisignoli 1970). A few metres from the camp that had been established, upon a visit from Mackinlay and Ulloa, the shelter was inaugurated with the name Teniente Luis Oscar Ventimiglia (Fig. 3).

The name honoured the station leader of the Melchior Naval Detachment in Antarctica during 


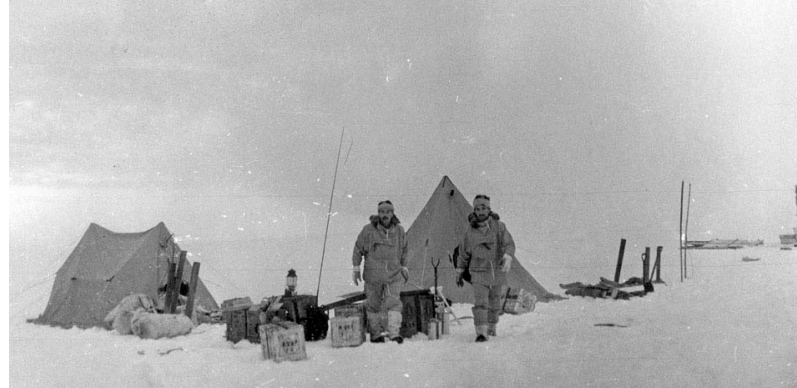

Figure 2. Photograph of the Argentine camp taken from the landed helicopter. Parts of the hut under construction and one of its walls can be seen in the background to the right. (DNA-IAA Archive of Historical Photography, AFH000459.)

the winter of 1958. Ventimiglia passed away on 18 May of that year during an emergency acute appendicitis surgery. His lifeless body was laid on a nearby glacier until the icebreaker ARA General San Martín transported him back to Buenos Aires to his final resting place (Pierrou 1981).

The hut was a prefabricated model similar to others set up in the 1970s by Argentina in Antarctica. The model consisted of plates with external aluminiumlined walls filled with insulating material, with a multilaminated wood interior. Its rectangular base was nearly square $(2.36 \times 2.46 \mathrm{~m})$, with the front and back panels slightly longer than the sides. There was a door at the front, which faced east, and each of its shorter sides had a small window. It was $2.25 \mathrm{~m}$ in height, with an additional $30 \mathrm{~cm}$ for the gabled roofing. Each corner was secured by a guy line held with an iron stake wedged into the ice. In photographs of the site, the Argentine-made Cacique brand tents can be identified as well as the sledges still used by the DNA-IAA. According to the testimony of Julio Ortíz, the DNA technician who participated in the installation of the shelter, they left inside provisions, sleeping bags, stoves, lamps, fuel, first aid kit and polar survival equipment (Ortíz, pers. comm.).

Although the hut was located on an island which was claimed by Norway in 1931, the 1959 Antarctic Treaty allowed the construction of the facility. Set up outside of the Argentine Antarctic Sector, the hut was also outside of the Chilean territorial claim, which would help to avoid Argentina's South American neighbour from viewing it as an expansion into claim. Neither country has facilities established in the territory solely claimed by the other; instead, their respective facilities are within their own territorial claims or in the region in which both claims overlap. The hut was the only Argentine Antarctic facility outside of the territorial claim of the UK, which contains the Argentine

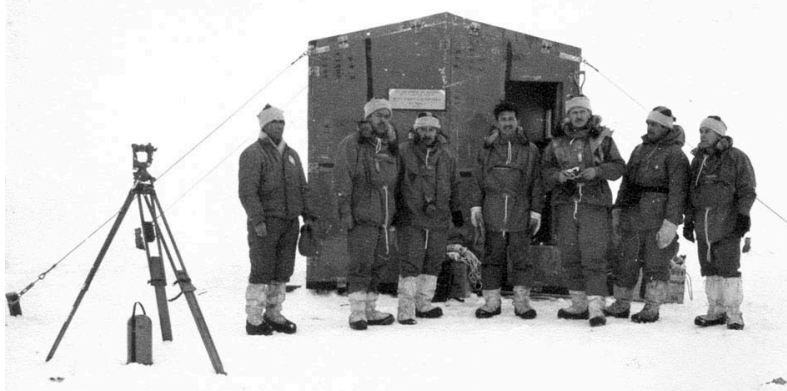

Figure 3. Inauguration of the Teniente (Lieutenant) Luis Ventimiglia hut on 3 March 1971 at 14:50. (Photograph by Raúl Leguina. DNA-IAA Archive of Historical Photography, AFH000462.)

Sector in its entirety as well as part of the Chilean claim.

For almost a week the icebreaker carried out a series of 16 oceanographic studies every four miles, measuring temperature, oxygen, phosphate, silicates and nitrates of the seawater to a depth of $2250 \mathrm{~m}$ (data available through the US National Oceanographic Data Center at www.nodc.noaa.gov). Other scientific studies were undertaken, in addition to an island reconnaissance that included aerial photography by helicopter (Armada de la República Argentina 1971). The results of the marine biological sampling were presented in two DNA-IAA publications. The first one, authored by Olga Blanco and Delma Bellusci de Miralles, describes a small collection of hydrozoa and provides information on their morphology (Blanco \& Bellusci de Miralles 1972). The second work, by the biologist Aldo Tomo (Fig. 4), who participated in the expedition, describes the fieldwork and research carried out from the icebreaker and includes notes on the ecology, ichthyology and invertebrates of the island (Tomo 1973). Among the scientific fieldwork carried out, geological samples were collected following a helicopter landing on Tvistein Pillars (Fig. 5).

On the night of $3 \mathrm{March}$, the scientists who had completed the construction of the hut were picked up. According to Ortiz, the pick-up was a surprise and took place while they were preparing for dinner inside the shelter: the original idea was that they would stay for a few days doing meteorological and geomagnetic studies. But because a strong storm was looming, it was decided aboard the icebreaker to evacuate immediately (Ortíz, pers. comm.). The return journey endured harsh sea conditions, which nearly led to the loss of the Alouette helicopter from its deck. The helicopter was only saved by the action of the crewmen and the commander of the icebreaker 


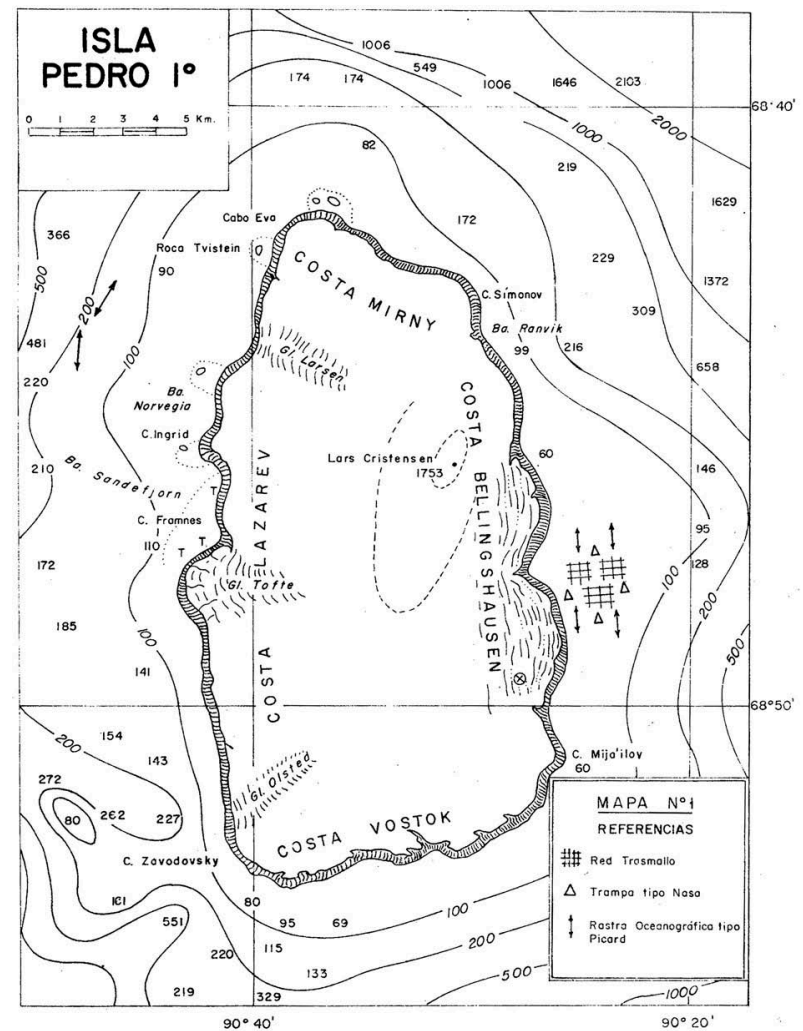

Figure 4. Map of Peter I Øy from the publication of Aldo Tomo (Tomo 1973).

in holding onto it with ropes (Alurralde, pers. comm.). That same day the icebreaker set sail towards Petrel Base, on Dundee Island, reaching its destination four days later.

In spite of the difficulties experienced, in the middle of that same year, Mackinlay, director of the IAA, issued a plan for the summer campaign 1972/73 in Peter I Øy that would involve two IAA groups remaining on the island for 60 days between December 1972 and February 1973 (IAA 1971): a group of two men, made up of meteorologist Julio Vergara and Rafael Delule, would occupy the Ventimiglia hut, carrying out meteorological, atmospheric and geomagnetic studies, while the second group, composed of Mario Cassis and Eduardo Branda, would explore the island to determine if it was possible to install a permanent station with a staff of 15 people to conduct studies in those three fields (DNA 1971). However, that summer, the difficulties in supplying Matienzo Base, in the Seal Nunataks on the Antarctic Peninsula, and the stranding of the Norwegian vessel MS Lindblad Explorer that required the assistance of the Argentine icebreaker, postponed the operation and resulted in a change of personnel. At the beginning of the campaign 17.62 tonnes of supplies was allocated for Peter I $\varnothing y$, but the icebreaker only took $6.36 \mathrm{TN}$ tonnes and only $142 \mathrm{~kg}$ were unloaded on the island by a Bell UH-1H Huey

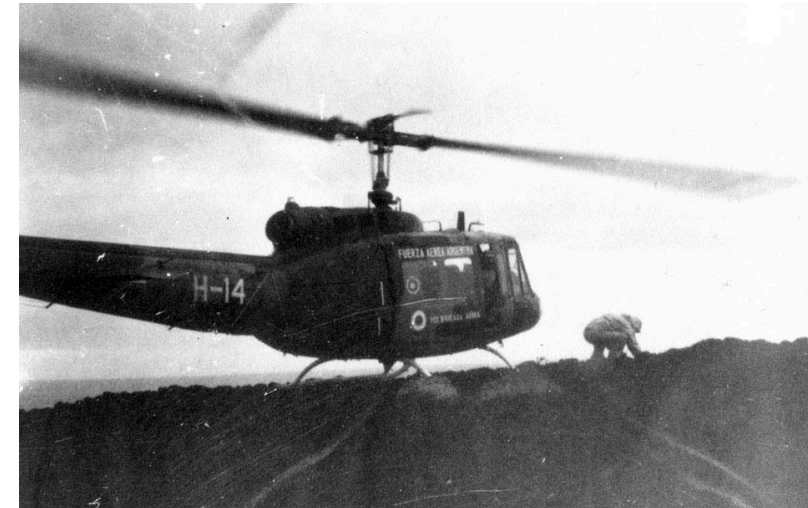

Figure 5. Landing on Tvistein Pillars and collection of rock samples on 3 March 1971 at 11:00. The helicopter is a Bell UH-1H Huey from the 7th Brigade of the Argentine Air Force. (DNA-IAA Archive of Historical Photography, AFH000457.)

helicopter, which made eight flights for personnel, cargo and exploration (Antarctic Naval Force 1972).

On 20 February, a group of five people was transported to the location of the Ventimiglia hut, but it was covered with snow and the building could not be seen. Fortunately, the brothers Mario and Alejandro Cassis, one of them an expert mountaineer, found it. The scientific group, composed by Gustavo Grumstrup and Eduardo Besada, both from the SMN, and Marcelo Sana, from the IAA, made scientific measurements of different types, particularly meteorological and geomagnetic (Fig. 6). The three scientists slept that night in the hut but the Cassis brothers spent the night in a snow cave. The tranquility was such that a watch could be heard ticking from a distance of several metres (Grumstrup, pers. comm.). The next day a storm began and they were picked up.

Again, the securing of the helicopters was a difficult task due to the rolling of the ship and on this occasion caused serious injury to the face of an officer of the vessel. The final report of the Antarctic Naval Force recommended continuing all the projects that had been undertaken in the summer campaign, with the exception of those carried out on Peter I Øy (Antarctic Naval Force 1972).

Because of the difficulties encountered, including challenging weather and terrain conditions, the original idea of maintaining a regular summer crew at Ventimiglia was discarded. Additionally, the particular meteorological conditions of the island proved that a station established there would not improve weather forecasting for the Antarctic Peninsula area, so the main purpose for the establishment of the hut was considered no longer valid. For these reasons the final report of the Antarctic Naval Force recommended not returning to Peter I $\varnothing \mathrm{y}$ and to abandon the hut (Antarctic Naval Force 1973). 


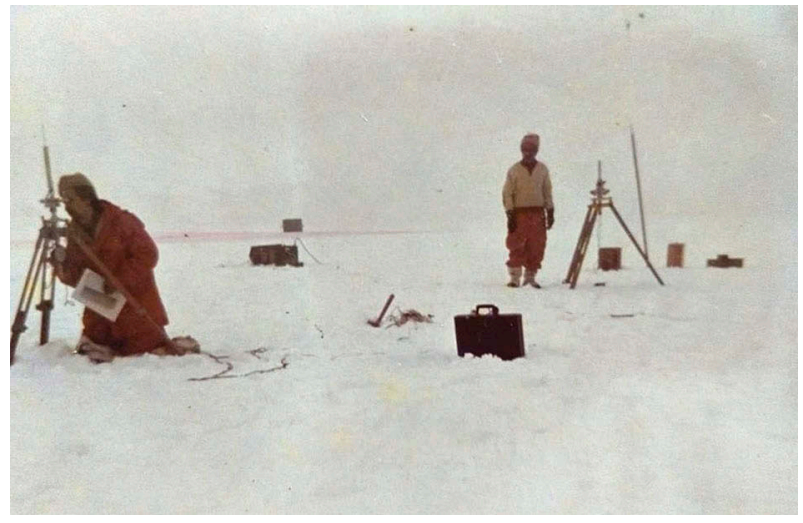

Figure 6. Grumstrup (left) and Besada (right) measuring the magnetic field. (Photograph by Gustavo Grumstrup.)

Given the glacio-meteorological conditions at the site where it was established, it is reasonable to suppose that the hut was buried in the snow and after years it may have collapsed into the sea together with ice as a result of the glacier displacement. Norwegian aerial photography taken in 1987 shows no evidence of the hut (Fig. 7), and none was found by several expeditions, many of which landed with helicopters in that small ice plain area. Today an automatic meteorological station is operated by the Alfred Wegener Institute of Germany at the site. Had the Argentines had such remote instrumentation back in 1971, they would not have established the Ventimiglia shelter, which ended up being a hut too far.

\section{Acknowledgements}

I would like to thank the following people for their help with the historical photographs: Andrés Zakrajsek, Manuel Cupeiro and José Luis Fornaro, all from the IAA. I am also grateful to Ivar Stokkeland of the Norwegian Polar Institute for providing the Peter I Øy aerial photographs. Máximo Gowland, from the National Directorate for Antarctic Foreign Policy of the Argentine Ministry of Foreign Affairs and Worship, Dolores Deregibus (IAA) and Adrian Howkins are thanked for their assistance and contributions to this manuscript. I am particularly grateful to the following people, who kindly agreed to be interviewed: Dalton Alurralde, Gustavo Grumstrup, Julio Ortíz and Roberto Ulloa. Interviews took place in 2018. Roberto Ulloa also permitted me to make use of his unpublished memoirs.

\section{Disclosure statement}

No potential conflict of interest was reported by the author.

\section{Funding}

I thank the Dirección Naciona de Antártico, Instituto Antártico Argentino.

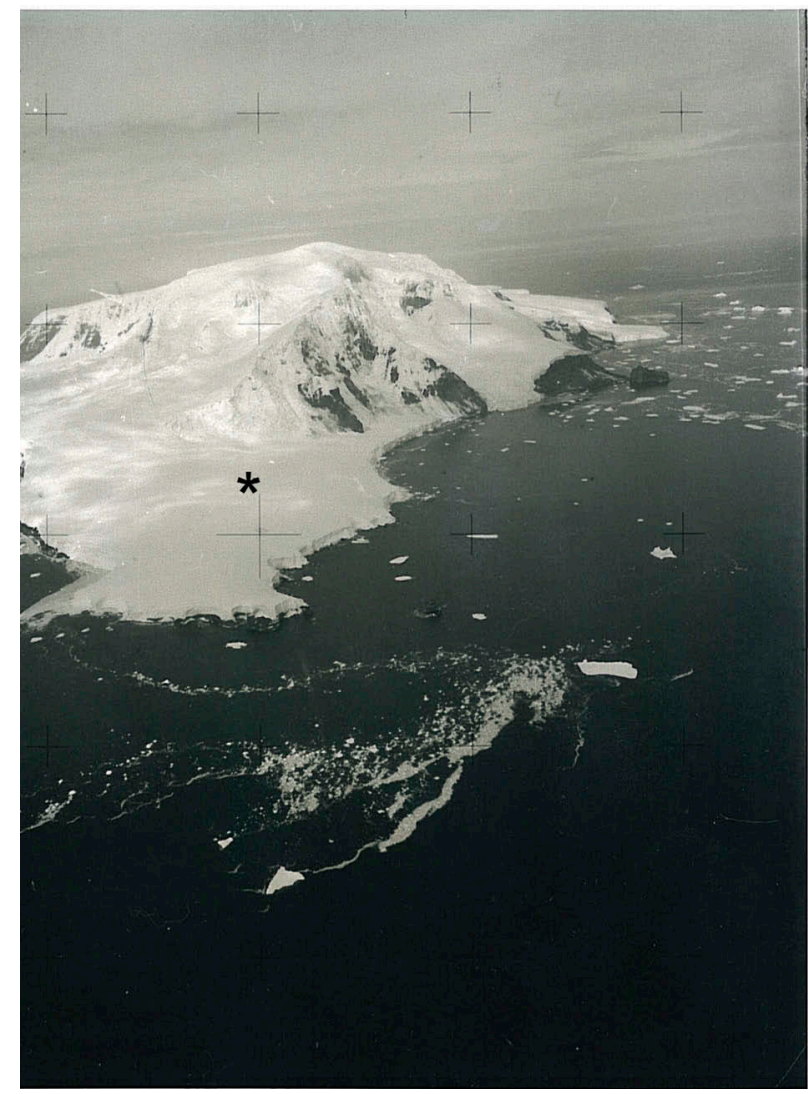

Figure 7. Peter I Øy from the north. Tvistein Pillars is off the north-western tip of the island. The location of the Ventimiglia shelter is marked with an asterisk. (Norwegian Polar Institute, aerial photo archive: Peter I Øy, 1987, image no. 430.)

\section{References}

Antarctic Naval Force (Fuerza Naval Antártica) 1971. Informe final de la Campaña Antártica de verano 1970/71. (Final report of the Antarctic summer campaign 1970/71.) Buenos Aires: General Archive of the Argentine Navy (Archivo General de la Armada Argentina).

Antarctic Naval Force (Fuerza Naval Antártica) 1972. Informe final de la Campaña Antártica de verano 1971/72. (Final report of the Antarctic summer campaign 1971/72.) Buenos Aires: General Archive of the Argentine Navy (Archivo General de la Armada Argentina).

Antarctic Naval Force (Fuerza Naval Antártica) 1973. Informe final de la Campaña Antártica de verano 1972/73. (Final report of the Antarctic summer campaign 1972/73.) Buenos Aires: General Archive of the Argentine Navy (Archivo General de la Armada Argentina).

Armada de la República Argentina 1965. Diario de navegación del rompehielos ARA Gral. San Martín 1783/2. (Logbook of the ARA General San Martín Icebreaker 1783/ 2.) Buenos Aires: General Archive of the Argentine Navy (Archivo General de la Armada Argentina).

Armada de la República Argentina 1971. Diario de navegación del rompehielos ARA Gral. San Martín 1785/1. (Logbook of the ARA General San Martín icebreaker 1785/1.) Buenos Aires: General Archive of the Argentine Navy (Archivo General de la Armada Argentina).

Barr S. 1987. Norway's polar territories. Oslo: Aschehoug. 
Blanco O. \& Bellusci de Miralles D. 1972. Contribución del Instituto Antártico Argentino no. 145: hidrozoos de la Isla Pedro I. (Contribution of the Argentine Antarctic Institute no. 145: hydrozoa of the Peter I Øy.) Buenos Aires: National Antarctic Directorate, Argentine Antarctic Institute.

Coli C. 2003. La Armada Argentina en la Antártida: campañas navales antárticas 1960-1980. (The Argentine Navy in Antarctica: Antarctic navy campaigns 19601980.) Buenos Aires: Antarctic Naval Force.

DNA (Dirección Nacional del Antártico) 1971. Nota 1298 al Comandante Antártico. (Note 1298 to the Antarctic Command.) Buenos Aires: National Antarctic Directorate, Argentine Antarctic Institute.

Estado Mayor del Grupo Naval Antártico 1964. Estudio sobre Isla Pedro I. (Study of Peter I Øy.) Buenos Aires: General Archive of the Argentine Navy (Archivo General de la Armada Argentina.
Leal J. 1971. Operación 90. (Operation 90.) Buenos Aires: National Antarctic Directorate, Argentine Antarctic Institute.

Lisignoli C.A. 1970. Informe de resultados sobre "Isla Pedro I." (Results report on "Peter I Øy".) Buenos Aires: General Archive of the Argentine Navy (Archivo General de la Armada Argentina).

Pierrou E. 1981. La Armada Argentina en la Antártida 1939-1959. (The Argentine Navy in Antarctica 19391959.) Buenos Aires: Instituto de Publicaciones Navales.

Tomo A. 1973. Contribución del Instituto Antártico Argentino no. 161: notas biológicas sobre la Isla Pedro I. (Contribution of the Argentine Antarctic Institute no. 161: biological notes about Peter I Øy.) Buenos Aires: National Antarctic Directorate, Argentine Antarctic Institute. 